\title{
Öğretmen Adaylarının Örnek Olaylara Ait Çözüm Stratejilerinin Çok yüzeyli Rasch Model ile İncelenmesi
}

\author{
Süleyman DEMiR ${ }^{1}$
}

Öz: Bu çalışmanın amacı mezun durumunda olan sınıf öğretmen adaylarının mesleki hayatlarına başladıklarında karşılaşmaları muhtemel sorunlar karşısında geliştirecekleri çözüm stratejilerinin incelenmesidir. Bu amaç doğrultusunda öncelikle sınıf öğretmeni olarak görev yapan öğretmenlerden görüş alınmış ve çözümünde zorlanılan iki örnek olay (alt 1slatma ve hırsızlık) belirlenmiştir. Mezun aşamasına gelmiş 38 öğretmen adayına oluşturulan örnek olaylar yazılı metin olarak verilmiş ve geliştirmiş oldukları çözüm stratejileri yine yazılı metin olarak toplanmıştır. Elde edilen çözüm stratejileri Sınıf öğretmenliği ve Rehberlik ve Psikolojik Danışmanlık alanlarında uzman ikişer akademisyen tarafından Çözüm Stratejileri Değerlendirme Rubriği kullanılarak puanlanmıştır. Verilerin çözümlenmesinde dört-yüzeyli Rasch model kullanılmış ve örnek olaylar, puanlayıcı, madde ve birey birer yüzey olarak belirlenmiştir. Analizler sonucunda örnek olaylar arasında bir farklılığın olmadığı, puanlayıcıların katılık ve cömertlik açısından birbirlerine çok yakın olduğu ve 1 numaralı maddenin (Öğretmen adayı kriz anında soğukkanlı davranabilmiştir) en kolay karşılandığı 5 numaralı maddenin ise (Yapılan müdahalenin gerekçesi öğrenciye anlatılmıştır) en zor karşılandığı görülmüştür.

Anahtar Sözcükler: Çok yüzeyli rasch modeli, Sınıf öğretmeni adayları, Örnek olay

\section{Examination of Teacher Candidates' Solution Strategies Regarding Case Studies with Many Facet Rasch Model}

\begin{abstract}
The study examines primary school teacher candidates' strategies for resolving problems they are likely to encounter as they begin their careers. For this purpose, two case studies were prepared of sample difficult problems teachers may encounter in the classroom (i.e., wetting and theft). Thirty-eight recently graduated schoolteacher candidates were given the two case studies and asked to write solution strategies for them. The strategies were scored using the Solution Strategies Evaluation Rubric by two academicians each from the areas of classroom teaching and guidance and psychological counseling. A four-facet Rasch model was used to analyze the data and case studies, raters, items, and the individuals. The analysis revealed no differences between the case studies; the raters agreed closely on rigidity and generosity.
\end{abstract}

Keywords: Many facet rasch model, Primary school teacher candidates, Case study 
Öğretmen adaylarının lisans eğitimi süresince almış oldukları dersler ile öğretmenlik yapabilir düzeye gelmeleri beklenmektedir. Bu dersler içerisinde Alan Eğitimi, Öğretmenlik Meslek Bilgisi ve Genel Kültür dersleri bulunmaktadır. Çoğunluğu teorik olan bu derslerdeki öğrenmelerde kazanmış oldukları beceriler, uygulama derslerinde davranışa dönüşmektedir. Öğretmen adayları Güz ve Bahar yarıyıllarındaki Öğretmenlik Uygulaması dersleri kapsamında haftada bir gün okula giderek öğretim elemanı ve uygulama öğretmeninin gözetiminde uygulama yapmaktadır. Uygulama öğretmeninin gözetiminde en fazla 4 öğretmen adayı bulunması Milli Eğitim Bakanlığı tarafından hazırlanan Öğretmenlik Uygulamasına İlişkin Yönerge'de belirlenmiştir (Öğretim elemanının ve uygulama öğretmeninin yeterli sayıda bulunması durumunda bölüm uygulama koordinatörlerinin kararları doğrultusunda bu sayı 2-3 olarak da belirlenebilmektedir). Bu 4 öğretmen adayı çoğunlukla aynı gün okula gitmekte ve aynı gün içerisinde tüm öğretmen adayı uygulama yapmaktadırlar. Öğretmen adayları toplamda (12+12) 24 defa uygulama okuluna gidip altı ders saati okulda bulunarak, kazanmış olduğu öğretmenlik mesleğine ilişkin becerileri uygulama firsatı bulur.

Milli Eğitim Bakanlığının hazırladığı öğretmenlik uygulamasına ilişkin yönergede, Öğretmenlik Uygulaması dersi öğretmen adaylarının eğitimini aldıkları ve ileride öğretmen olarak görev yapacakları alana ait öğretimleri gerçek sınıf ortamında dersleri planlayıp öğrencilere öğretmesini sağlayan ve öğretim faaliyetlerine yönelik farklı tecrübeler kazandıran uygulamalı bir ders olarak tanımlanmaktadır (MEB, 2018). Öğretmen adaylarının bu dersten yüksek düzeyde verim almaları onların fazla sayıda uygulama yapmaları ile mümkündür. Fazla uygulama yapmaları onlara farklı yaşantılarla karşılaşma fırsatı sağlayarak deneyimlerinin artmasına ve karşılaştıkları bu farklı yaşantılarla ilgili uygulama öğretmeni ve öğretim elemanına danışma imkanı sağlamaktadır. Unutulmamalıdır ki bu öğretmen adayları öğretmen olduktan sonra sınıfta tek otorite konumunda olacak ve karşılaştıkları farklı yaşantıların üstesinden kendi kararları ile geleceklerdir. Öğretmenlik mesleğindeki ilk yıllarının daha sağlıklı ve verimli olabilmesi için fazla sayıda uygulamaya ihtiyaç vardır.

Öğretmen adayları uygulamalar esnasında sınıf yönetimi, öğretim yöntem ve tekniklerinin uygulanması, alan bilgisi, iletişim, ölçme ve değerlendirme konularında kendilerini yetersiz görmekte (Bay, Şeker ve Alisinanoğlu, 2020; Karadüz, Eser, Şahin ve İlbay, 2009; Selvi, Doğru, Gencosman ve Saka, 2017; Taşdere, 2014) ve öğretmenlik uygulaması sürelerinin yetersiz olduğu ve uygulama saatlerinin arttırılmasını istemektedirler (Altıntaş ve Görgen, 2014; Aslan ve Sağlam, 2018; Eraslan, 2009; Kavas ve Bugay, 2009; Selvi ve diğerleri, 2017; Taşdere, 2014). Ayrıca öğretmen adayları, aynı gün içerisinde 4 öğretmen adayının uygulama yapmasından dolayı uygulama süresinin kısıtlı olması, uygulama öğretmeninin öğretmen adaylarına güvenmemesi ya da fazla güvenmesinden dolayı uygulamaların yetersiz ve etkisiz olduğunu ifade etmektedirler (Boz ve Boz 2006; Taşdere, 2014). Uygulama yapılması amacıyla öğretim planında yer alan bu ders kapsamında uygulamaların yetersiz ve etkisiz olması, öğretmenliğe başlamaya çok yaklaşmış olan öğretmen adaylarının meslekten soğumalarına, özgüvenlerini kaybetmelerine neden olması muhtemeldir. Yeterli uygulama fırsatı bulamayan öğretmen adaylarının mesleki hayatlarına başladıklarında uzun bir süre sınıf ortamında öğrenciler ile sorun yaşamaları ve bu sorunlarla baş etmede başarısız olmaları kaçınılmazdır.

Alanyazın incelendiğinde sınıfların kalabalık olmasını, özellikle köy okullarının temizlik ve materyal yetersizliği, öğrencilerin sorunlarının çözümünde yetersiz kalmaları, görev yaptıkları/ikamet ettikleri yerleşim yerlerinin sosyal ve kültürel olanaklarının yetersizliği ve resmi işlemler açısından lisans eğitimlerinin yetersizliği sınıf öğretmenlerinin görevlerine ilk başladıklarında, yaşamış oldukları sorunlar olarak belirlenmiştir (Karataş ve Kınalığlu, 2018; Kozan, Emeksever ve Onur Sezer, 2019; Kozikoğlu ve Senemoğlu, 2018). Özellikle köy okullarında ve birleştirilmiş sınıflarda görev yapan sınıf öğretmenlerinin ulaşım, barınma, ısınma gibi fizyolojik ihtiyaçların temini konusunda sorun yaşadıkları doğu ve güneydoğu illerinde görev yapan öğretmenlerin ise öğrenciler ve velileri ile iletişim kurmada sıkıntı yaşadıklarını ifade etmektedirler (Karataş ve Kınalığlu, 2018; Sağ, Savaş ve Sezer, 2009; Şahin, ve Analı, 2019). Sınıf öğretmenlerinin yaşamış oldukları; öğrenci motivasyonunu arttırma, öğrencinin ilgisini çekme, sınıf kurallarını belirleme ve uygulama gibi sorunların lisans eğitiminde bulunan sınıf yönetimi dersinin 
yetersizliğinden kaynaklandığı düşünülmektedir (Korkmaz, 1999; Kozikoğlu ve Senemoğlu, 2018; Sünbül, 2005; Sarı ve Altun, 2015; Şahin, ve Analı, 2019; Yuen Fun, 1991). Öğrencilerin karşılaşacakları ilk öğretmenlerinden olan sınıf öğretmenlerinin sorunları çözmede kullanacağı yöntemler, öğrencilerin tüm yaşamlarında olumlu veya olumsuz etkiler bırakabilecektir. Sınıf öğretmenleri, uyarma, görmezden gelme, rehberlik servisine gönderme vb. (Çetin, 2013) çözümler ile karşılaştıkları sorunların üstesinden gelmeye çalışmaktadırlar. Ancak bu çözümlerin gerçekte ne kadar etkili olduğu ve bu çözümlerin uygulamasını gerçekleştirirken nasıl bir süreç yaşandığı ve sonucunda öğrencide nasıl etkiler bırakacağına ilişkin çalışmalara rastlanamamıştır.

$\mathrm{Bu}$ çalışmanın amacı mezun durumunda olan sınıf öğretmenliği adaylarının mesleki hayatlarına başladıklarında karşılaşmaları muhtemel sorunlar karşısında geliştirecekleri çözüm stratejilerinin incelenmesidir. Bu amaç doğrultusunda öncelikle sınıf öğretmeni olarak görev yapan öğretmenler ile görüş alınmış ve çözümünde zorlanılan iki örnek olay belirlenmiştir. Bu örnek olaylar sınıf öğretmenliği anabilim dalında mezun aşamasında bulunan öğretmen adaylarına yazılı olarak sunulmuş ve çözüm stratejileri yazılı olarak elde edilmiştir. Elde edilen bu çözüm stratejileri 4 adet alan uzmanı tarafından puanlanmıştır.

\section{Yöntem}

\section{Araştırma Türü}

$\mathrm{Bu}$ çalışmada sınıf öğretmen adaylarının mesleki hayatlarında karşılaşabilecekleri problemler karşısında geliştirecekleri çözüm stratejilerinin incelenmesi amaçlanmaktadır. Alan yazın incelendiğinde var olan durumun ortaya koymayı amaçlayan çalışmalar için betimsel tarama modelinin uygun araştırma modeli olduğu ifade edilmektedir. Bu yüzden çalışmamızda betimsel tarama modeli kullanılmıştır (Büyüköztürk, Kılıç Çakmak, Akgün, Karadeniz, ve Demirel, 2014; Karasar, 2016).

\section{Örnek Olayların Belirlenmesi}

Milli Eğitim Bakanlığı bünyesindeki devlet okullarında görev yapmakta olan 21 sınıf öğretmeninden, mesleki hayatlarında öğrenciler ile yaşadıkları ve çözüm üretmekte zorlandıkları problemlerin neler olduğuna yönelik görüş alınmıştır. Görüş alınan 21 öğretmen, Sakarya Üniversitesi, Eğitim Fakültesi, Sınıf öğretmenliği programında yürütülen Öğretmenlik Uygulaması I-II derslerinde uygulama öğretmeni olarak görev almaktadır. Bu öğretmenlerin öğretmen adaylarına rehberlik yapabilmeleri için ilgili üniversite tarafından verilen "Eğitimcilerin Eğitimi" sertifikasına sahip olmaları gerekmektedir. Ayrıca görüş alınan öğretmenler, en az 10 yıllık kıdeme sahip olmaları, en az iki farklı coğrafi bölgede görev yapmış olmaları, her sınıf kademesinde en az iki defa eğitim dönemini tamamlamış olmaları ve en az dört yıl boyunca köy okulunda görev yapma kriterleri göz önünde bulundurularak belirlenmiştir. Öğretmenlere "Öğrencilerle sınıf içerisinde yaşamış olduğunuz ve çözümün üretmekte zorlandığınız problemler nelerdir?" sorusu yöneltilmiş ve öğretmenlerden görüşler yazılı olarak toplanmıştır. Bu görüşler doğrultusunda frekansı en yüksek problemlerin "alt ıslatma", "hırsızlık", "yabancı uyruklu öğrencinin adaptasyon problemi" ve "kaynaştırma yoluyla eğitimine devam eden öğrencinin dışlanması" olduğu belirlenmiştir. Bu problemlerden "yabancı uyruklu öğrencinin adaptasyon problemi" ve "kaynaştırma yoluyla eğitimine devam eden öğrencinin dışlanması" ile ilgili Milli Eğitim Müdürlükleri bünyesinde hizmetiçi eğitimlerin bulunmasından dolayı, araştırma kapsamına "alt ıslatma" ve "hırsızlık" problemleri dâhil edilmiştir. Belirlenen bu problemler öğrencilere sunulmak üzere örnek olay haline dönüştürülmüştür (EK.1).

\section{Çalışma Grubu}

Araştırmanın çalı̧̧ma grubu, Sakarya Üniversitesi, Eğitim Fakültesi, Sınıf öğretmenliği programında mezun aşamasına gelmiş 38 öğretmen adayından oluşturulmuştur. Bu 38 öğretmen adayının gönüllük esasına dayalı olarak çalışma grubuna dahil edilmiştir. Ayrıca çalışma grubuna alınacak öğretmen adaylarının Öğretmenlik Uygulaması (I ve II) dersleri ile sınıf yönetimi dersini almış ve başarı ile tamamlamış olmalarına dikkat edilmiştir. Çalışma grubundaki öğretmen adaylarının tamamı uygulama yapılan dönem sonu itibariyle mezun olabilecek durumdadırlar. Çalışma grubundaki öğretmen adaylarının \%73.69'u kız (28) ve \%26.31'i ise erkektir (10). Çalışma sonrasında Sınıf Eğitimi ve Rehberlik ve Psikolojik 
Danışmanlık ABD'nda görev yapan birer akademisyenin katılımıyla bir seminer düzenlenmiş ve bu ve benzeri örnek olaylarla karşılaşıldığında nelere dikkat etmeleri gerektiği ile ilgili bilgilendirme yapılmıştır.

\section{Veri Toplama Aracı}

38 öğretmen adayının, iki örnek olay için geliştirmiş oldukları çözüm stratejilerinin değerlendirilmesi araştırmacı tarafından geliştirilmiş “Çözüm Stratejileri Değerlendirme Rubriği" kullanılmıştır. Alanyazın taraması sonucunda oluşturulan rubrik kullanılmadan önce, Ölçme ve Değerlendirme, Rehberlik ve Psikolojik Danışmanlık, Eğitim Yönetimi ve Denetimi ve Sınıf Eğitimi alanında görev yapmakta olan 10 akademisyenden rubriğin geçerliğini test etmek amacıyla uzman görüşü alınmıştır. Rubriğin geçerliğinin test edilmesi için basit uyum katsayısı hesap edilmiştir. Uzman görüşleri sonucunda \%70 ve üzerinde uyuma sahip maddeler rubriğe dahil edilebilmektedir (Erkuş, 2006). Rubrikte bulunan maddeler için hesap edilen basit uyum katsayıları \%85 ile \%100 aralığında değişmekte olduğu için tüm maddelerin rubriğe alınmasına karar verilmiştir (EK.2).

\section{Çözüm stratejilerinin değerlendirilmesi}

2019-2020 akademik yılı bahar dönemi sonucunda Sakarya Üniversitesi, Eğitim Fakültesi, Sınıf Öğretmenliği ABD'ndan mezun aşamasına gelmiş 38 öğretmen adayına oluşturulan örnek olaylar yazılı metin olarak verilmiş ve geliştirmiş oldukları çözüm stratejileri yine yazılı metin olarak toplanmıştır. Ede edilen çözüm stratejileri Sınıf öğretmenliği ve Rehberlik ve Psikolojik Danışmanlık alanlarında uzman ikişer akademisyen tarafından Çözüm Stratejileri Değerlendirme Rubriği kullanılarak puanlanmıştır. Öğretmen adaylarından elde edilen çözüm stratejilerinin puanlanması sırasında puanlayıcıların birbirinden etkilenmemeleri amacıyla öğretmen adaylarının çözüm stratejileri her bir puanlayıcı için çoğaltılmışır. Puanlayıcılardan elde edilen değerlendirme sonuçları Excel programına girilerek analize hazır hale getirilmiştir.

\section{Verilerin Analizi}

Öğretmen adaylarının mesleki hayatlarında karşılaşabilecekleri muhtemel olaylara karşı geliştirecekleri çözüm stratejileri, Linacre (1993) tarafından geliştirilmiş FACETS programı kullanılarak çok yüzeyli Rasch modeli ile analiz yapılmıştır. Verilerin çözümlenmesinde dört-yüzeyli Rasch modelin kullanılmış ve örnek olaylar, puanlayıcı, madde ve birey birer yüzey olarak belirlenmiştir. Çok yüzeyli Rasch modeli analizinde diğer yöntemlerden farklı olarak tüm değişkenler birer yüzey olarak ele alınır ve yüzeylere ait puanlar belirlenirken diğer yüzeylerin etkisi ortadan kaldırllır (Eckes, 2019; Linacre, 1994; Sudweeks, Reeve ve Bradshaw, 2005; Zhu, Ennis ve Chen, 1998). Çok yüzeyli Rasch modeli analizi özellikle birden fazla puanlayıcının bulunduğu durumlarda, puanlayıcı etkisinin ortadan kaldırılması amacıyla sıklıkla kullanılmaktadır.

Çok yüzeyli Rasch modeli analizinde öncelikle model veri uyumunun test edilebilmesi için standartlaştırılmış artık değerlerin incelenmesi gerekmektedir. Model veri uyumunun sağlanabilmesi için \pm 2 ile \pm 3 aralığının dışında bulunan standartlaştırılmış artık değerlerin toplam verinin sırasıyla \%5 ile \%1'den fazla olmaması gerekmektedir (Lincare, 2014). Yapılan çalışmada (2 örnek olay x 4 puanlayıcı $\times 38$ birey $\times 8$ kriter) toplam 1824 veri bulunmaktadır. \pm 3 aralığının dışında bulunan standartlaştırılmış artık değerlerin toplam veriye oranı \%0.004 iken \pm 2 aralığının dışında bulunan standartlaştırılmış artık değerlerin toplam veriye oranı \% 0.05 'tir. Elde edilen bu sonuca göre verinin dört yüzeyli Rasch model ile kabul edilebilir düzeyde uyuma sahip olduğu söylenebilir.

Verilerin analizi aşamasında tüm yüzeylere ait infit ve outfit indeksleri, güvenirlik, ayırma oranı ve kikare değerleri verilmiştir. Bu değerlerden infit ve outfit değerlerinin mükemmel değeri 1 olmasına rağmen kabul edilebilir aralık 0.6 ile 1.4 olarak kabul edilmektedir (Wright ve Linacre, 1994). Infit ve outfit değerlerinin 0.6 ile 1.4 aralığında olması verinin model ile iyi uyuma sahip olduğunu göstermektedir. Ayırma oranı ve güvenlik katsayılarının ilgili yüzeydeki bileşenlerin yüksek düzeyde ayırt edilebildiğini göstermektedir ve güvenirlik katsayısının 0.80 'den büyük olması, ayırma oranının ise 2 'den büyük olması beklenmektedir. (Güler, 2014; Linacre, 2014; Wright ve Linacre, 1994). Ayırma oranı ve güvenirlik 
katsayılarına benzer şekilde ki-kare istatistiğinin anlamlı $(\mathrm{p}<0.05)$ çıkması ilgili yüzeydeki bileşenlerin ayırt edilebildiğini göstermektedir.

\section{Bulgular}

\section{İki örnek olaya ilişkin dört-yüzeyli Rasch analizi sonuçları}

Bu bölümde öncelikle dört yüzeyli rasch analizi sonucunda elde edilen kalibrasyon haritası verilmiş daha sonrasında ise her bir yüzey için elde edilen analiz sonuçları verilmiştir. Alt ıslatma ve hırsızlık örnek olaylarının her ikisi için bireylerin geliştirdikleri çözüm stratejilerinin değerlendirilmesi amacıyla yapılan dört-yüzeyli Rasch modeline (puanlayıcı, olay, madde, birey) ilişkin veri kalibrasyon haritası Şekil 1'de verilmiştir. Veri kalibrasyon haritası puanlayıcıların katılık-cömertlikleri, örnek olayların çözümünde zorlanma düzeyleri, bireylerin başarı sıralamaları ve ölçütlerin karşılanma düzeyleri hakkında bilgi vermektedir.

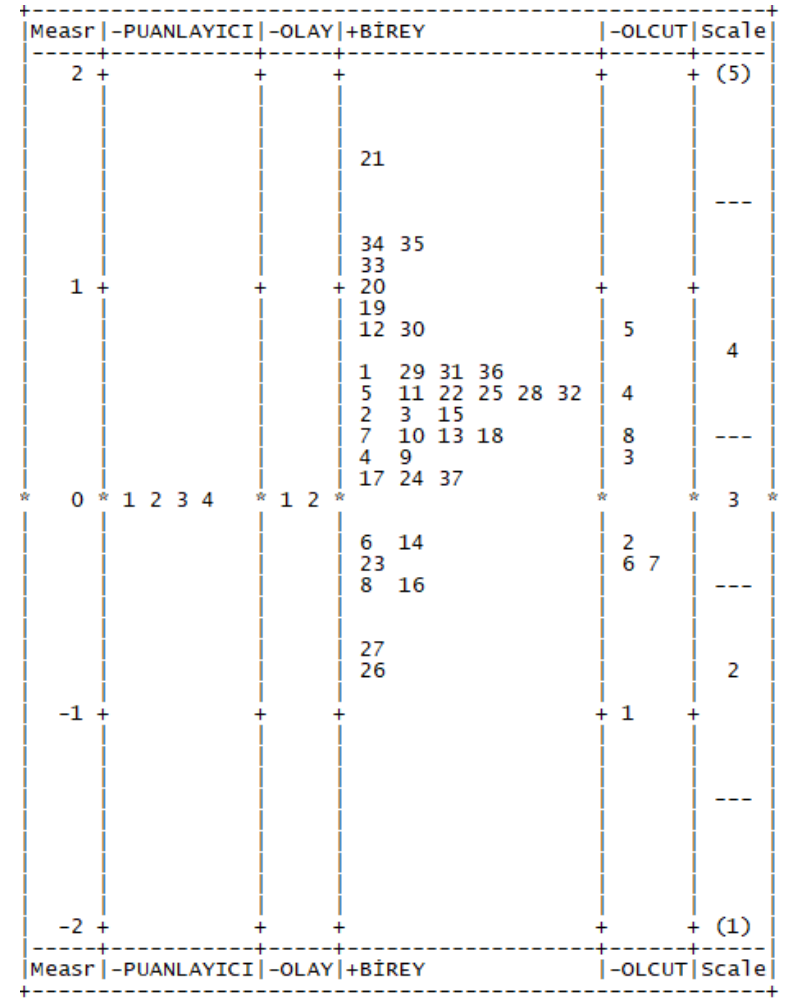

Şekil 1. Dört-yüzeyli Rasch modeline ilişkin veri kalibrasyon haritası

Şekil 1 incelendiğinde birinci sütun puanlayıclar, ikinci sütun örnek olaylar, üçüncü sütun bireyler ve dördüncü sütun ise kriterler için elde edilen logit değerlerine göre sıralandığı görülmektedir. Kalibrasyon haritasının birinci sütunundaki logit değerler aşağıdan yukarıya doğru gidildikçe puanlayıcıların cömertliklerinin arttığına işaret etmektedir. Buna göre puanlayıcıların birbirlerine yakın puanlamalar yaptığı ve arasında bir farklılığın olmadığı görülmektedir. Kalibrasyon haritasının ikinci sütunundaki logit değerler aşağıdan yukarıya doğru gidildikçe örnek olayların çözümünde zorlanma düzeylerinin arttığına işaret etmektedir (veri analizinde negatif olarak belirtilmiştir). Buna göre örnek olayların çözümlenmesinde aralarında bir farklılığın olmadığı görülmektedir. Kalibrasyon haritasının üçüncü sütunundaki logit değerler aşağıdan yukarıya doğru gidildikçe bireylerin başarı düzeylerinin arttığına işaret etmektedir. Buna göre en başarılı çözüm stratejisine sahip bireyin 21 numaralı birey olduğu, en başarısız çözüm stratejisinin ise 26 numaralı bireye ait olduğu görülmektedir. Kalibrasyon haritasının dördüncü sütunundaki logit değerler aşağıdan yukarıya doğru gidildikçe kriterlerin karşılanma düzeylerinin arttığına işaret etmektedir. Buna göre bireylerin geliştirmiş oldukları çözüm stratejilerinde en zor karşılanan maddenin 5 numaralı madde olduğu (Yapılan müdahalenin gerekçesi öğrenciye anlatılmıştır), en kolay karşılanan maddenin ise 1 
numaralı madde olduğu (Öğretmen adayı kriz anında soğukkanlı davranabilmiştir) görülmektedir.

Şekil 2'de puanlayıcıların çözüm stratejilerini değerlendirmelerine ilişkin analiz sonuçları verilmiştir. Puanlayıcılara ait logit değerler incelendiğinde, 1 ve 2 numaralı puanlayıcıya ait logit değerlerin -0.03 olduğu, 3 numaralı puanlayıcıya ait logit değerinin 0.03 olduğu ve 4 numaralı puanlayıcıya ait logit değerinin 0.02 olduğu görülmektedir. Her bir puanlayıcı için hesap edilen infit ve outfit istatistiklerinin 0.6 ile 1.4 aralığında olması model veri uyumunun sağlandığına işaret etmektedir.

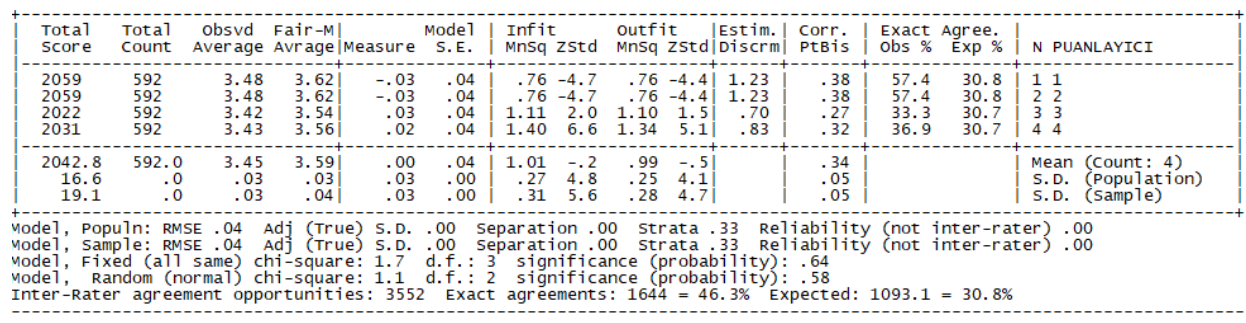

Şekil 2. Puanlayıcıların çözüm stratejilerini değerlendirmelerine ilişkin analiz sonuçları

Şekil 2 incelendiğinde puanlayıcı yüzeyi için hesap edilen ayırma oranı ile güvenirlik katsayılarının 0.00 olması ve ki-kare istatistiğinin anlamlı olmaması $\left(X^{2}=1.7, \mathrm{sd}=3, \mathrm{p}>0.05\right)$ puanlayıcıların birbirinden istatistiksel olarak anlamlı olacak düzeyde ayırt edilemediğini göstermektedir. Bir diğer ifadeyle puanlayıcılar katılık ve cömertlik açısından benzer özellikler taşımaktadırlar.

Şekil 3'de örnek olayların değerlendirmelerine ilişkin analiz sonuçları verilmiştir. Örnek olaylara ait logit değerler incelendiğinde 1 numaralı örnek olay ait logit değerinin -0.04 olduğu 2 numaralı örnek olaya ait logit değerinin 0.04 olduğu görülmektedir. Örnek olaylar için hesap edilen infit ve outfit istatistiklerinin 0.6 ile 1.4 aralığında olması model veri uyumunun sağlandığına işaret etmektedir.

\begin{tabular}{|c|c|c|c|c|c|c|c|c|c|c|c|c|}
\hline $\begin{array}{l}\text { Total } \\
\text { Score }\end{array}$ & $\begin{array}{l}\text { Total } \\
\text { Count }\end{array}$ & $\begin{array}{c}\text { Obsvd } \\
\text { Average }\end{array}$ & $\begin{array}{l}\text { Fair-M } \\
\text { Avrage }\end{array}$ & Measure & $\begin{array}{l}\text { Model } 1 \\
\text { S.E. }\end{array}$ & $\begin{array}{l}\text { Inf it } \\
\text { Mnsq }\end{array}$ & zstd & $\begin{array}{l}\text { Outfi } \\
\text { Mnsq }\end{array}$ & $\begin{array}{l}\text { it } \\
\text { zstd }\end{array}$ & $\left|\begin{array}{l}\text { Estim. } \\
\text { Discrm }\end{array}\right|$ & $\begin{array}{l}\text { Corr. } \\
\text { PtBis }\end{array}$ & N OLAY \\
\hline $\begin{array}{l}4133 \\
4038\end{array}$ & $\begin{array}{l}1184 \\
1184\end{array}$ & $\begin{array}{l}3.49 \\
3.41\end{array}$ & $\begin{array}{l}3.63 \\
3.54\end{array}$ & $\begin{array}{l}-.04 \\
.04\end{array}$ & $\begin{array}{l}.03 \\
.03\end{array}$ & $\begin{array}{l}1.05 \\
.98\end{array}$ & $\begin{array}{l}1.2 \\
-.6\end{array}$ & $\begin{array}{r}1.02 \\
.95\end{array}$ & $\begin{array}{r}.4 \\
-1.0\end{array}$ & $\begin{array}{r}.94 \\
1.06\end{array}$ & $\begin{array}{l}.32 \\
.35\end{array}$ & $\begin{array}{ll}1 & 1 \\
2 & 2\end{array}$ \\
\hline $\begin{array}{r}4085.5 \\
47.5 \\
67.2\end{array}$ & $\begin{array}{r}1184.0 \\
.0 \\
.0\end{array}$ & $\begin{array}{r}3.45 \\
.04 \\
.06\end{array}$ & $\begin{array}{r}3.58 \\
.05 \\
.07\end{array}$ & $\begin{array}{l}.00 \\
.04 \\
.05\end{array}$ & $\begin{array}{l}.03 \\
.00 \\
.00\end{array}$ & $\begin{array}{l}1.01 \\
.04 \\
.05\end{array}$ & $\begin{array}{r}.3 \\
.9 \\
1.3\end{array}$ & $\begin{array}{l}.99 \\
.03 \\
.05\end{array}$ & $\begin{array}{r}-.3 \\
.8 \\
1.1\end{array}$ & & $\begin{array}{l}.33 \\
.01 \\
.02\end{array}$ & $\begin{array}{l}\text { Mean (Count: 2) } \\
\text { S.D. (Population) } \\
\text { S.D. (Sample) }\end{array}$ \\
\hline $\begin{array}{l}\text { del, Pop } \\
\text { del, sam } \\
\text { de1, Fix }\end{array}$ & $\begin{array}{l}\text { lin: RMS } \\
\text { ple: RMS } \\
\text { ed (a17 }\end{array}$ & $\begin{array}{l}\mathrm{SE} .03 \\
\mathrm{SE} .03 \\
\text { same) }\end{array}$ & $\begin{array}{l}\text { Adj (Tru } \\
\text { Adj (Tru } \\
\text { hi-squar }\end{array}$ & $\begin{array}{l}\text { Le) S.D. } \\
\text { ue) S.D. } \\
\text { e: } 3.5\end{array}$ & $\begin{array}{ll}.02 & 5 \\
.04 & 5 \\
\text { d.f. : }\end{array}$ & $\begin{array}{l}\text { separat } i \\
1 \\
1 \text { sign }\end{array}$ & & $\begin{array}{lrr}86 & \mathrm{str} \\
858 & \mathrm{st} \\
\text { ance } & \mathrm{pp}\end{array}$ & & $\begin{array}{l}1.49 \mathrm{RE} \\
2.44 \\
\text { bi ity) }\end{array}$ & $\begin{array}{l}\text { Reliabil } \\
: .06\end{array}$ & $\begin{array}{l}y .43 \\
\text { ty } .71\end{array}$ \\
\hline
\end{tabular}

Şekil 3. Örnek olayların değerlendirmesine ilişkin analiz sonuçları

Şekil 3 incelendiğinde örnek olay yüzeyi için hesap edilen ayırma oranı ile güvenirlik katsayılarının 0.86 ve 0.43 olması ve ki-kare istatistiğinin anlamlı olmaması ( $\left.X^{2}=3.5 \mathrm{sd}=1, \mathrm{p}>0.05\right)$ örnek olayların birbirinden istatistiksel olarak anlamlı olacak düzeyde ayırt edilemediğini göstermektedir. Bir diğer ifadeyle örnek olaylar kolaylık zorluk açısından benzer özellikler taşımaktadırlar.

Şekil 4'te bireylerin geliştirmiş oldukları çözüm stratejileri açısından başarı durumlarına ilişkin analiz sonuçları verilmiştir. Bireylere ait logit değerler incelendiğinde en yüksek logit değer 21 numaralı bireye ait iken, en düşük logit değer 26 numaralı bireye ait olduğu görülmektedir. Bireyler için hesap edilen infit ve outfit istatistiklerinin (8 ve 33 numaralı bireyler haricinde), 0.6 ile 1.4 aralığında olması model veri uyumunun sağlandığına işaret etmektedir. 


\begin{tabular}{|c|c|c|c|c|c|c|c|c|c|c|}
\hline $\begin{array}{l}\text { Total } \\
\text { score }\end{array}$ & $\begin{array}{l}\text { Total } \\
\text { count }\end{array}$ & $\begin{array}{c}\text { obsvd } \\
\text { Aver age }\end{array}$ & $\begin{array}{l}\text { Fair-M } \\
\text { Avrage } \mid\end{array}$ & Measure & $\begin{array}{l}\text { Model } \\
\text { S.E. }\end{array}$ & $\begin{array}{l}\text { Infit } \\
\text { Mnsq zstd }\end{array}$ & $\begin{array}{l}\text { Outfit } \\
\text { Mnsq Zstd }\end{array}$ & $\left|\begin{array}{l}\text { Estim. } \\
\mid \text { Discrm }\end{array}\right|$ & $\begin{array}{l}\text { corr. } \\
\text { PtBis }\end{array}$ & NU BÍREY \\
\hline $\begin{array}{l}243 \\
223 \\
226 \\
208 \\
231 \\
180 \\
220 \\
163 \\
206 \\
221 \\
231 \\
231 \\
252 \\
217 \\
224 \\
224 \\
158 \\
203 \\
218 \\
259 \\
265 \\
290 \\
234 \\
171 \\
201 \\
231 \\
132 \\
141 \\
232 \\
239 \\
251 \\
238 \\
230 \\
268 \\
274 \\
274 \\
237 \\
199\end{array}$ & $\begin{array}{l}64 \\
64 \\
64 \\
64 \\
64 \\
64 \\
64 \\
64 \\
64 \\
64 \\
64 \\
64 \\
64 \\
64 \\
64 \\
64 \\
64 \\
64 \\
64 \\
64 \\
64 \\
64 \\
64 \\
64 \\
64 \\
64 \\
64 \\
64 \\
64 \\
64 \\
64 \\
64 \\
64 \\
64 \\
64 \\
64 \\
64\end{array}$ & 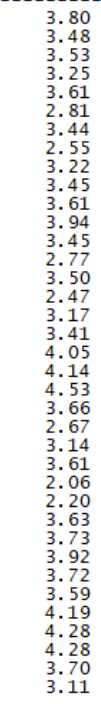 & $\begin{array}{l}3.90 \\
3.58 \\
3.53 \\
3.32 \\
3.71 \\
2.81 \\
3.52 \\
2.50 \\
3.28 \\
3.54 \\
3.71 \\
4.04 \\
3.54 \\
2.75 \\
3.59 \\
2.49 \\
3.24 \\
3.43 \\
4.15 \\
4.24 \\
4.59 \\
3.76 \\
2.64 \\
3.19 \\
3.71 \\
1.95 \\
2.11 \\
3.73 \\
3.84 \\
4.03 \\
3.82 \\
3.69 \\
4.28 \\
4.37 \\
4.37 \\
3.81 \\
3.15\end{array}$ & $\begin{array}{r}.65 \\
.37 \\
.41 \\
.18 \\
-.48 \\
-.33 \\
-.38 \\
.15 \\
.34 \\
.48 \\
.79 \\
.34 \\
-.20 \\
-.38 \\
-.45 \\
.30 \\
.30 \\
1.01 \\
1.63 \\
.52 \\
-.28 \\
.09 \\
.48 \\
-.82 \\
-.68 \\
.49 \\
.79 \\
.77 \\
.47 \\
1.07 \\
1.20 \\
1.20 \\
.56 \\
.07\end{array}$ & $\begin{array}{l}.12 \\
.11 \\
.11 \\
.12 \\
.11 \\
.11 \\
.11 \\
.11 \\
.12 \\
.13 \\
.11 \\
.11 \\
.11 \\
.11 \\
.11 \\
.13 \\
.14 \\
.12 \\
.11 \\
.11 \\
.12 \\
.12 \\
.12 \\
.12 \\
.13 \\
.12 \\
.12 \\
.15 \\
.15 \\
.12 \\
.11\end{array}$ & 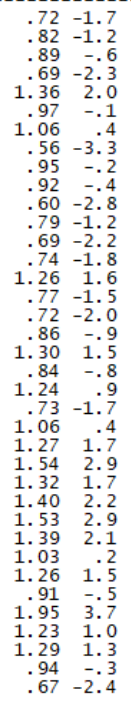 & 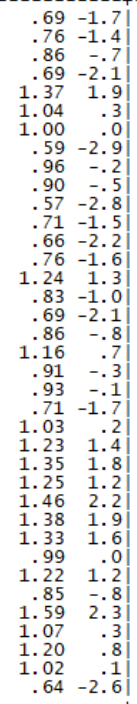 & \begin{tabular}{|r}
1.04 \\
1.24 \\
1.20 \\
1.13 \\
.55 \\
.71 \\
.87 \\
1.36 \\
1.11 \\
.96 \\
1.52 \\
1.28 \\
1.40 \\
1.07 \\
.76 \\
1.16 \\
1.40 \\
1.27 \\
.98 \\
.94 \\
1.06 \\
1.10 \\
.82 \\
.65 \\
.60 \\
1.02 \\
.78 \\
.64 \\
.71 \\
1.10 \\
.76 \\
1.08 \\
.72 \\
.98 \\
.92 \\
.90 \\
1.50
\end{tabular} & $\begin{array}{l}.21 \\
.29 \\
.26 \\
.26 \\
.21 \\
.22 \\
.36 \\
.29 \\
.27 \\
.40 \\
.36 \\
.27 \\
.28 \\
.31 \\
.34 \\
.34 \\
.27 \\
.26 \\
.27 \\
.25 \\
.25 \\
.22 \\
.22 \\
.25 \\
.25 \\
.32 \\
.21 \\
.30 \\
.24 \\
.21 \\
.23 \\
.35\end{array}$ & $\begin{array}{ll}1 & 1 \\
2 & 2 \\
3 & 3 \\
4 & 4 \\
5 & 5 \\
5 & 5 \\
7 & 6 \\
8 & 7 \\
8 & 8 \\
9 & 9 \\
10 & 10 \\
11 & 11 \\
12 & 12 \\
13 & 13 \\
14 & 14 \\
15 & 15 \\
16 & 16 \\
17 & 17 \\
19 & 18 \\
19 & 19 \\
20 & 20 \\
21 & 21 \\
22 & 22 \\
23 & 23 \\
24 & 24 \\
25 & 25 \\
26 & 26 \\
27 & 27 \\
28 & 28 \\
29 & 29 \\
31 & 30 \\
31 & 31 \\
32 & 32 \\
34 & 33 \\
35 & 34 \\
36 & 35 \\
37 & 37\end{array}$ \\
\hline $\begin{array}{r}220.8 \\
36.5 \\
37.0\end{array}$ & $\begin{array}{r}64.0 \\
.0 \\
.0\end{array}$ & $\begin{array}{r}3.45 \\
.57 \\
.58\end{array}$ & $\begin{array}{r}3.51 \\
.62 \\
.63\end{array}$ & $\begin{array}{l}.38 \\
.52 \\
.52\end{array}$ & $\begin{array}{l}.12 \\
.01 \\
.01\end{array}$ & $\begin{array}{rr}1.03 & .0 \\
.31 & 1.8 \\
.32 & 1.8\end{array}$ & $\begin{array}{ll}.99 & -.21 \\
.27 & 1.5 \\
.27 & 1.6\end{array}$ & & $\begin{array}{l}.27 \\
.06 \\
.06\end{array}$ & $\begin{array}{l}\text { Mean (Count: 37) } \\
\text { S.D. (Population) } \\
\text { S.D. (Sample) }\end{array}$ \\
\hline 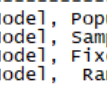 & indom (no & ormat) ch & & & & $\begin{array}{l}36 \text { signif } \\
35 \text { signifi }\end{array}$ & $\begin{array}{l}\text { ficance (prob } \\
\text { icance (prob }\end{array}$ & & 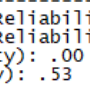 & ${ }^{4}$ \\
\hline
\end{tabular}

Şekil 4. Bireylerin geliştirmiş oldukları çözüm stratejilerinin başarı durumlarına ilişkin analiz sonuçları

Şekil 4 incelendiğinde birey yüzeyi için hesap edilen ayırma oranı ile güvenirlik katsayılarının 4.10 ve 0.94 olması ve ki-kare istatistiğinin anlamlı olması $\left(X^{2}=574.75 \mathrm{sd}=36, \mathrm{p}<0.05\right)$ bireylerin birbirinden istatistiksel olarak anlamlı olacak düzeyde ayırt edildiğini göstermektedir. Bir diğer ifadeyle bireyler örnek olaylara yönelik geliştirdikleri çözüm stratejileri açısından farklılık göstermektedirler. Buna göre bireylerin geliştirdikleri çözüm stratejileri incelendiğinde en başarılı çözüm stratejisinin 21 numaralı bireye ait olduğu (EK.3), en başarısız çözüm stratejisinin ise 26 numaralı bireye ait olduğu (EK.4) görülmüştür.

Şekil 5'te Çözüm Stratejileri Değerlendirme Rubriğindeki ölçütlerin karşılanma düzeylerine ilişkin analiz sonuçları verilmiştir. Kriterlere ilişkin logit değerler incelendiğinde en yüksek logit değer 5. ölçüte ait iken, en düşük logit değer 1. ölçüte aittir. Ölçütler için hesap edilen infit ve outfit istatistiklerinin (8. ölçüt haricinde), 0.6 ile 1.4 aralığında olması model veri uyumunun sağlandığına işaret etmektedir.

\begin{tabular}{|c|c|c|c|c|c|c|c|c|c|c|c|c|}
\hline $\begin{array}{l}\text { Total } \\
\text { Score }\end{array}$ & $\begin{array}{l}\text { Total } \\
\text { Count }\end{array}$ & $\begin{array}{l}\text { obsvd } \\
\text { Average }\end{array}$ & $\mid \begin{array}{l}\text { Fair-M } \\
\text { Avrage }\end{array}$ & Measure & $\begin{array}{l}\text { Mode1 } \\
\text { S.E. }\end{array}$ & $\begin{array}{l}\text { Infit } \\
\text { Mnsq }\end{array}$ & zstd & $\begin{array}{l}\text { Outfi } \\
\text { Mnsq }\end{array}$ & zstd & $\left|\begin{array}{l}\text { Estim. } \\
\text { Discrm }\end{array}\right|$ & $\begin{array}{l}\text { Corr. } \\
\text { PtBis }\end{array}$ & N OLCUT \\
\hline $\begin{array}{r}1304 \\
1098 \\
971 \\
850 \\
748 \\
1151 \\
1124 \\
925\end{array}$ & $\begin{array}{l}296 \\
296 \\
296 \\
296 \\
296 \\
296 \\
296 \\
296\end{array}$ & $\begin{array}{l}4.41 \\
3.71 \\
3.28 \\
2.87 \\
2.53 \\
3.89 \\
3.80 \\
3.13\end{array}$ & $\begin{array}{l}4.48 \\
3.80 \\
3.33 \\
2.86 \\
2.46 \\
3.99 \\
3.89 \\
3.15\end{array}$ & $\begin{array}{r}-1.01 \\
-.18 \\
.19 \\
.51 \\
.78 \\
-.35 \\
-.26 \\
.31\end{array}$ & $\begin{array}{l}.08 \\
.06 \\
.05 \\
.05 \\
.05 \\
.06 \\
.06 \\
.05\end{array}$ & $\begin{array}{r}.69 \\
.80 \\
.78 \\
1.14 \\
.91 \\
.82 \\
.92 \\
1.75\end{array}$ & $\begin{array}{r}-3.2 \\
-2.7 \\
-3.3 \\
2.0 \\
-1.3 \\
-2.2 \\
-1.0 \\
9.0\end{array}$ & $\begin{array}{r}.71 \\
.81 \\
.77 \\
1.18 \\
.90 \\
.82 \\
.95 \\
1.75\end{array}$ & $\begin{array}{r}-2.7 \\
-2.3 \\
-3.3 \\
2.3 \\
-1.3 \\
-2.1 \\
-.5 \\
8.5\end{array}$ & $\begin{array}{r}1.12 \\
1.23 \\
1.36 \\
.54 \\
.95 \\
1.18 \\
.92 \\
.31\end{array}$ & $\begin{array}{l}.29 \\
.32 \\
.32 \\
.19 \\
.25 \\
.31 \\
.20 \\
.24\end{array}$ & $\begin{array}{ll}1 & 1 \\
2 & 2 \\
3 & 3 \\
4 & 4 \\
5 & 5 \\
6 & 6 \\
7 & 7 \\
8 & 8\end{array}$ \\
\hline $\begin{array}{r}1021.4 \\
169.2 \\
180.9\end{array}$ & $\begin{array}{r}296.0 \\
.0 \\
.0\end{array}$ & $\begin{array}{r}3.45 \\
.57 \\
.61\end{array}$ & $\begin{array}{r}3.49 \\
.62 \\
.66\end{array}$ & $\begin{array}{l}.00 \\
.53 \\
.57\end{array}$ & $\begin{array}{l}.06 \\
.01 \\
.01\end{array}$ & $\begin{array}{l}.98 \\
.32 \\
.34\end{array}$ & $\begin{array}{l}-.4 \\
3.9 \\
4.2\end{array}$ & $\begin{array}{l}.99 \\
.32 \\
.34\end{array}$ & $\begin{array}{l}-.2 \\
3.7 \\
4.0\end{array}$ & & $\begin{array}{l}.27 \\
.05 \\
.05\end{array}$ & $\begin{array}{l}\text { Mean (Count: 8) } \\
\text { S.D. (Population) } \\
\text { S.D. (Sample) }\end{array}$ \\
\hline 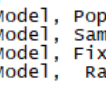 & $\begin{array}{l}\text { Aln: RMS } \\
\text { ole: RMS } \\
\text { ed (a11 } \\
\text { ndom (no }\end{array}$ & $\begin{array}{l}\text { ISE .06 } \\
\text { ISE .06 } \\
\text { same) } \\
\text { ormal) } \\
\text { ormat }\end{array}$ & $\begin{array}{l}\text { Adj (Tru } \\
\text { hi-squar } \\
\text { chi-squar }\end{array}$ & $\begin{array}{l}\text { S.D. } \\
\text { S.D. } \\
592.0 \\
6.9\end{array}$ & $\begin{array}{l}.53 \\
.56 \\
0.5 \\
\text { d.f. } \\
\text { d.f.: }\end{array}$ & $\begin{array}{l}\text { separati } \\
\text { separati } \\
: 7 \text { si } \\
6 \text { sign }\end{array}$ & & $\begin{array}{ll}20 & \text { st! } \\
35 & \text { str } \\
\text { cance } \\
\text { cce } & \text { (pr }\end{array}$ & $\begin{array}{l}\text { trata } \\
\text { trata } \\
\text { (prob } \\
\text { probab }\end{array}$ & $\begin{array}{l}12.60 \\
13.46 \\
\text { bability } \\
\text { bility) }\end{array}$ & $\begin{array}{l}\text { Reliabi } \\
\text { Reliabi } \\
\text { y): }: .00 \\
: .33\end{array}$ & $\begin{array}{l}\text { ity }: 99 \\
\text { ity :99 }\end{array}$ \\
\hline
\end{tabular}

Şekil 5. Maddelerin karşılanma düzeylerine ilişkin analiz sonuçları

Şekil 5 incelendiğinde ölçüt yüzeyi için hesap edilen ayırma oranı ile güvenirlik katsayılarının 9.20 ve 0.99 olması ve ki-kare istatistiğinin anlamlı olması ( $\left.X^{2}=592.0 \mathrm{sd}=7, \mathrm{p}<0.05\right)$ ölçütlerin birbirinden istatistiksel olarak anlamlı olacak düzeyde ayırt edildiğini göstermektedir. Bir diğer ifadeyle ölçütler karşılanma düzeyleri açısından farklılık göstermektedirler. Bireylerin geliştirmiş oldukları çözüm stratejilerinde en zor karşılanan maddenin 5 numaralı madde olduğu (Yapılan müdahalenin gerekçesi öğrenciye anlatılmıştır), en kolay karşılanan maddenin ise 1 numaralı madde olduğu (Öğretmen adayı kriz anında soğukkanlı davranabilmiştir) görülmüştür. 


\section{Sonuç ve Tartışma}

Bu çalışmada sınıf öğretmenliği adaylarının mesleki hayatlarında karşılaşabilecekleri alt sslatma ve hırsızlık olaylarını çözebilmek amacıyla geliştirecekleri çözüm stratejileri değerlendirilmiştir. Analizler sonucunda örnek olaylar arasında bir farklılığın olmadığı, puanlayıcıların katılık ve cömertlik açısından birbirlerine çok yakın olduğu ve 1 numaralı maddenin (Öğretmen adayı kriz anında soğukkanlı davranabilmiştir) en kolay karşılandığı, 5 numaralı maddenin ise (Yapılan müdahalenin gerekçesi öğrenciye anlatılmıştır) en zor karşılandığı görülmüştür. Ayrıca dört yüzeyli Rasch modeline göre en başarılı çözüm stratejisinin 21 numaralı bireye, en başarısız çözüm stratejisinin ise 26 numaralı bireye ait olduğu belirlenmiştir.

Kalibrasyon haritasında birey yüzeyinde görüldüğü üzere öğretmen adaylarının \%19'unun logit değerinin sıfırın altındadır. Kalibrasyon haritasında sıfır logit değerin ortalamayı ifade ettiği (Linacre, 1994) düşünüldügünde öğretmen adaylarının \%19'unun örnek olaylara ilişkin geliştirmiş oldukları çözüm stratejilerinin başarısız olduğu söylenebilir. Öğretmen adaylarının mesleki hayatlarında başarılı olmaları alan bilgisi ve pedagojik alan bilgisine sahip olmalarının yanı sıra yaratıcı düşünme, problem çözme, iletişim, kurma ve iş birlikli çalışma, medya ve iletişim teknolojilerinin etkili kullanılması, vatandaşlık bilinci, kişisel ve sosyal sorumluluk gibi farklı becerilere de sahip olmasını gerektirmektedir (Eret Orhan, 2017; Schleicher, 2012). Bu becerilerin bazıları lisans eğitiminde verilen teorik ve uygulamalı dersler ile sağlanabilmesine rağmen, bazıları ise öğretmen adaylarının kişisel gelişimleri ile mümkündür. Öğretmen adaylarının bu çalışmada sunulan örnek olaylarda daha başarılı olabilmeleri lisans eğitimlerinde aldıkları eğitim psikolojisi, sınıf yönetimi, okul deneyimi ve öğretmenlik uygulaması derslerinin daha etkili olması ile mümkündür.

Sınıf yönetimi dersi lisans eğitiminde tüm öğretmenlik programlarında olduğu gibi sınıf öğretmenliği programında da iki saatlik teorik bir ders olarak verilmektedir. Sınıf yönetimi dersi kapsamında öğretmen adaylarının "sınıf kuralları ve sınıfta disiplin; sınıfta öğrenci davranışlarının yönetimi, sınıfta iletişim ve etkileşim süreci; sınıfta öğrenci motivasyonu; okul kademelerine göre sınıf yönetimiyle ilgili örnek olaylar" gibi konularda bilgi donanımına sahip olmaları beklenmektedir (YÖK, 2018). Öğretmen adaylarının bu becerileri kazanmaları beklenmesine rağmen bu derslerin çoğunlukla teorik olarak yapıldığı ve öğrencilerin pasif olarak dinleyici olarak derse devam ettikleri görülmektedir. Öğretmen adaylarının bu becerileri kazanabilmeleri için mutlaka uygulamaya ihtiyaçları vardır (Çubukçu ve Girmen, 2008; Ercoşkun ve Ada 2013; Külekçi Akyavuz, 2020; Özay Köse, 2010).

Öğretmen adaylarının sınıf yönetimi de dahil olmak üzere tüm lisans derslerinde kazanmış oldukları becerileri uygulama fırsatı buldukları tek ders öğretmenlik uygulaması dersleridir. Öğretmenlik uygulaması dersi iki dönemde iki saati teorik olarak öğretim elemanı ile yürütülmekte iken altı saati ise uygulama öğretmeni ve öğretim elemanının gözetiminde yürütülmektedir. Her hafta sadece altı saat uygulama okuluna giden öğretmen adayları (gruplarında 4 kişi bulunmasından dolayı) en fazla bir ders saatinde uygulama yapabilmektedirler. Özellikle sınıf öğretmen adayları düşünüldügünde dört farklı sınıf düzeyinden sadece birinde uygulama yapma fırsatı bulmaktadırlar. Meslek hayatlarına başladıklarında diğer üç sınıf düzeyinde karşılaşacakları sorunları tek başlarına çözmek zorunda kalacaklarıdır. Ayrıca sınıf öğretmen adaylarının çoğunlukla şehir merkezinde bulunan uygulama okullarında staj yapmalarına rağmen, ilk görev yerlerinin çoğunlukla köy okulları ve Türkiye'nin doğusundaki şehirler olması (Eret Orhan, 2017) bu uygulama derslerinin gerçek yaşantılardan çok uzak kalmasına neden olmaktadır. Öğretmenlik uygulaması dersinin bir diğer yürütücüsü olan öğretim elemanı da öğretmenlik uygulaması dersinin etkili olmasında önemli bir faktördür (Boz ve Boz 2006; Taşdere, 2014). Öğretim elemanının, öğretmen adayını sınıf ortamında gözlemlemesi ve geri dönüt vermesi, bu uygulamalarda öğretmen adaylarının eksik yönlerini fark edip bu eksik yönleri geliştirmeleri için onlara rehberlik etmesi son derece önemlidir. Ancak yapılan çalışmalarda öğretim elemanının öğretmen adaylarını uygulama okullarında gözlemlemediği, dolayısıyla geri dönüt vermediği, alan uzmanı olmadığı için bu dersleri yürütmek zorunda olması öğretim elemanının bu derslerde etkisiz bir role sahip olmasına neden olmaktadır (Altıntaş ve Görgen, 2014; Aslan ve Sağlam, 2018; Bay, Şeker ve Alisinanoğlu, 2020; Eraslan, 2009; Karadüz, Eser, Şahin 
ve İlbay, 2009; Kavas ve Bugay, 2009; Selvi ve diğerleri, 2017; Taşdere, 2014). Sınıf öğretmen adaylarının bu örnek olaylarda başarısız olmasının nedenleri arasında; uygulama saatlerinin ve sayısının yetersiz olması, her seviyede öğrenciye uygulama fırsatının olmaması, okulda öğretmen olarak görülmemesi, öğretim elemanın süreçte etkisiz olması, uygulamalı olarak verilmesi gereken Sınıf Yönetimi dersinin teorik olarak verilmesi ve öğretmen adaylarının kişisel gelişimleri olarak ifade edilebilir (Aslan ve Sağlam, 2018; Aytaçli, 2012; Eraslan, 2009; Görgen, Çokçalışkan ve Korkut, 2012; Hudson, Uşak ve Savran Gencer, 2010; Kavas ve Bugay, 2009; Selvi ve diğerleri, 2017; Şimşek, Alkan ve Erdem, 2013; Taşdere, 2014).

Dört yüzeyli Rasch modeli ile elde edilen sonuçlara göre puanlayıcılar arasında katılık ve cömertlik açısından bir farklılığın olmadığı bulgusuna ulaşılmıştır. Çok yüzeyli rasch modelinin kullanıldığı çalışmalarda da puanlayıcılar arasında katılık ve cömertlik açısından farklılı̆̆ın olduğu (Baştürk, 2008; Baştürk, 2010; Çetin ve İlhan, 2017; Kaya Uyanık, Güler, Taşdelen Teker, ve Demir, 2017; Kaya Uyanık, Güler, Taşdelen Teker, ve Demir, 2018; Köse, Usta ve Yandı, 2016; Semerci, 2011; Yüzüak, Yüzüak ve Kaptan, 2015) ve puanlayıcılar arasında katılık ve cömertlik açısından farklılığın olmadığı (Akın ve Baştürk, 2012) çalı̧̧malar bulunmaktadır. Puanlayıcılar arasındaki farklılık, puanlayıcıların eğitim düzeylerindeki farklılıklardan kaynaklı olabileceği gibi kullanılan rubriklerden de olabilir.

$\mathrm{Bu}$ çalışmadan elde edilen bulgular göz önüne alındığında sınıf öğretmen adaylarının mesleki hayatlarında başarılı olabilmeleri için uygulama sayısının arttırılarak daha fazla deneyim kazanmaları, sınıf öğretmen adaylarının her sınıf düzeyinde ve farklı farklı öğrenme alanlarında uygulama yapması (Örneğin, güz döneminin tamamını 1. ve 3 sınıf düzeyinde, bahar döneminin tamamını ise 2. ve 4. sınıf görev yapan uygulama öğretmen adayının gözetiminde), lisans eğitiminde sınıf öğretmen adaylarına karşılaşabilecekleri problemler ve çözüm stratejileri ile ilgili bir ders verilmesi önerilebilir.

\section{Yazarın Beyanı}

Araştırmacıların katkı oranı beyanı: Araştırmanın tüm aşamaları yazar tarafından yapılmıştır.

Etik Kurul Kararı: Sakarya Üniversitesi, Sosyal ve Beşeri Bilimler Etik Kurulu Başkanlığııın 01.07.2020 tarihli ve 25 sayil toplantı

Çatışma beyanı: Herhangi bir kişi/kurum/kuruluşlarla herhangi bir çıkar çatışması yoktur.

Destek ve teşekkür: Çalışmanın devam ettirilmesinde emek harcayan puanlayıcılara (T.S.Ç, B.D, M.A.H, E.H.) desteklerinden dolayı çok teşekkür ediyorum.

\section{Kaynaklar}

Akın, Ö., \& Baştürk, R. (2012). Keman eğitiminde temel becerilerin Rasch ölçme modeli ile değerlendirilmesi. Pamukkale Üniversitesi Eğitim Fakültesi Dergisi, 31(1), 175-187.

Altıntaş, S., \& Görgen, İ. (2014). Sınıf öğretmeni adaylarının öğretmenlik uygulaması üzerine görüşleri (Muğla Sıtkı Koçman Üniversitesi örneği). Turkish Studies, 9(8), 197-208.

Aslan, M., \& Sağlam, M. (2018). Öğretmenlik uygulaması dersinin öğretmen adaylarının görüşlerine göre değerlendirilmesi. Hacettepe Üniversitesi Ĕ̆itim Fakültesi Dergisi, 33(1), 144-162

Aytaçlı, B. (2012). İlköğretim Matematik Öğretmenliği Lisans Programında Yer Alan Okul Deneyimi ve Öğretmenlik Uygulaması Derslerinin Değerlendirilmesi. (Yayımlanmamış Yüksek Lisans Tezi). Ege Üniversitesi, İzmir.

Baştürk, R. (2008). Applying the many facet Rasch model to evaluate PowerPoint presentation performance in higher education. Assessment and Evaluation in Higher Education, 33(4), 431-444.

Baştürk, R. (2010). Bilimsel araştırma ödevlerinin çok yüzeyli Rasch ölçme modeli ile değerlendirilmesi. Ĕ̆itimde ve Psikolojide Ölçme ve Değerlendirme Dergisi, 1(1), 51-57. 
Bay, D. N., Şeker, P. T., \& Alisinanoğlu, F. (2020). Öğretmenlik uygulaması dersine ilişkin öğretmen adaylarının görüşleri. Anadolu Üniversitesi Ĕ̆itim Fakültesi Dergisi (AUJEF), 4(1), 1-20.

Boz, N., \& Boz, Y. (2006). Do prospective teachers get enough experience in school placements? Journal of Education for Teaching, 32(4), 353-368.

Büyüköztürk, Ş., Kılıç Çakmak, E., Akgün, Ö.E., Karadeniz, Ş., \& Demirel, F. (2014). Bilimsel araştırma yöntemleri. Ankara: Pegem Yayınları

Çetin, B. (2013). Sınıfta istenmeyen öğrenci davranışlarıyla ilgili sınıf öğretmenlerinin karşılaştıkları sorunlar ve çözüm önerileri. Ahi Evran Üniversitesi Kırşehir Eğitim Fakültesi Dergisi (KEFAD), 14(1), 255-269.

Çetin, B., \& İlhan, M. (2017). An analysis of rater severity and leniency in open-ended mathematic questions rated through standard rubrics and rubrics based on the SOLO taxonomy. Eğitim ve Bilim, 42(189).

Çubukçu, Z, \& Girmen, P. (2008). Öğretmenlerin Sınıf Yönetimi Becerilerine İlişkin Görüşleri. Bilig (44) , 123142.

Eckes, T. (2019). Implications for rater-mediated language assessment. V. Aryadoust ve M. Raquel, (Ed.), Quantitative Data Analysis for Language Assessment Volume I: Fundamental Techniques (s. 153-175) içinde. London: Routledge.

Eraslan, A. (2009). İlköğretim matematik öğretmen adaylarının" öğretmenlik uygulaması" üzerine görüşleri. Necatibey Eğitim Fakültesi Elektronik Fen ve Matematik Ĕ̆itimi Dergisi, 3(1), 207-221.

Ercoşkun, M, \& Ada, Ş. (2013). Etkili Sınıf Yönetimi Oluşturmada Sınıf Öğretmenlerinin Yeni Rollerinin Nitel Açısından İncelenmesi. Adnan Menderes Üniversitesi Eğitim Fakültesi Eğitim Bilimleri Dergisi, 4(1), 60-79.

Eret Orhan, E. (2017). Türkiye'de öğretmen adayları aldıkları öğretmen eğitimi hakkında ne düşünüyor? Nitel bir araştırma. Eğitim ve Bilim, 42(189), 197-216.

Erkuş. A. (2006). Sınıf Öğretmenleri Iç̧in Ölçme ve Değerlendirme: Kavramlar ve Uygulamalar. Ankara: Ekinoks.

Görgen, İ., Çokçalışkan, H., \& Korkut, Ü. (2012). Öğretmenlik uygulaması dersinin öğretmen adayları, uygulama öğretmenleri ve uygulama öğretim üyeleri açısından işlevselliği. Muğla Üniversitesi Sosyal Bilimler Enstitüsü Dergisi, 28, 56-72.

Güler, N. (2014). Analysis of Open-Ended Statistics Questions with Many Facet Rasch Model. Eurasian Journal of Educational Research. 55, 73-90.

Hudson, P., Uşak, M., \& Savran Gencer, A. (2010). Benchmarking mentoring practices: a case study in Turkey. Eurasia Journal of Mathematics, Science \& Technology Education, 6(4), 245-252.

Karadüz A., Eser, Y., Şahin, C., \& İlbay, A.B., (2009). Eğitim fakültesi son sınıf öğrencilerinin görüşlerine göre öğretmenlik uygulaması dersinin etkililik düzeyi. Mustafa Kemal Üniversitesi Sosyal Bilimler Enstitüsü Dergisi, 6(11), 442-455.

Karasar, N. (2016). Bilimsel araştırma yöntemi: Kaynaklar ilkeler teknikler. Ankara: Nobel yayıncılık.

Karataş, A., \& Kınalığlu, İ. H. (2018). Köy okullarında çalışan sınıf öğretmenlerinin sorunları. Uşak Üniversitesi Sosyal Bilimler Dergisi 11(3), 207-220.

Kavas, A. B., \& Bugay, A. (2009). Öğretmen adaylarının hizmet öncesi eğitimlerinde gördükleri eksiklikler ve çözüm önerileri. Pamukkale Üniversitesi Ĕ̆itim Fakültesi Dergisi, 25, 13-21.

Kaya Uyanık, G., Güler, N., Taşdelen Teker, G., \& Demir, S. (2017). Türkiye'de Eğitim Alanında Yayımlanan Ölçek Geliştirme Çalışmalarının Uygunluğunun Çok Yüzeyli Rasch Modeli ile İncelenmesi. Journal of Measurement and Evaluation in Education and Psychology, 8(2), 183-199.

Kaya Uyanık, G., Güler, N., Taşdelen Teker, G., \& Demir, S. (2018). Fen bilimleri dersi etkinliklerinin çok düzeyli Rasch modeliyle analizi. Kastamonu Ĕ̆itim Dergisi, 27(1), 139-150. 
Korkmaz, S. (1999). Göreve yeni başlayan öğretmenlerin mesleğe uyum sorunları. (Yayınlanmamış Yüksek Lisans Tezi). Kocaeli Üniversitesi, Sosyal Bilimler Enstitüsü, Kocaeli.

Kozan, D., Emeksever, A., \& Onur Sezer, G. (2019). Öğrenme ortamlarının fiziksel düzeni açısından sınıf öğretmenlerinin karşılaştıkları sorunlar. Bolu Abant İzzet Baysal Üniversitesi Ĕğitim Fakültesi Dergisi, 19(4), 1177-1189.

Kozikoğlu, İ., \& Senemoğlu, N. (2018). Mesleğe yeni başlayan öğretmenlerin karşılaştıkları güçlükler: Nitel bir çözümleme. Eğitimde Nitel Araştırmalar Dergisi, 6(3), 341-371.

Köse, İ. A., Usta H. G., \& Yandı, A. (2016). Sunum yapma becerilerinin çok yüzeyli Rasch analizi ile değerlendirilmesi. Abant İzzet Baysal Üniversitesi Eğitim Fakültesi Dergisi, 16(4), 1853-1864.

Külekçi Akyavuz, E. (2020). Öğretmen Adaylarının Sınıf Yönetimi Yeterliğinin Belirlenmesi ve Geliştirilmesine Yönelik Öneriler. Marmara Üniversitesi Atatürk Eğitim Fakültesi Eğitim Bilimleri Dergisi, 52, 324-347.

Linacre, J. M. (1993). Generalizability theory and many facet Rasch measurement. annual meeting of the American Educational Research Association. (April, 13, 1993), (ED 364 573). Atlanta Georgia.

Linacre, J. M. (2014). A user's guide to FACETS Rasch-model computer programs. http://www.winsteps.com/a/facets-manual.pdf adresinden 06.12.2020 tarihinde alınmıştır.

MEB (2018). Öğretmen adaylarının Milli Eğitim Bakanlığına bağlı eğitim öğretim kurumlarında yapacakları öğretmenlik uygulamasına ilişkin yönerge. http://mevzuat.meb.gov.tr/dosyalar/263.pdf adresinden 14.12.2020 tarihinde alınmıştır.

Özay Köse, E. (2010). Sınıf yönetimine yönelik öğretmen adaylarının görüşleri. Çukurova Üniversitesi Eğitim Fakültesi Dergisi, 3(39), 20-27.

Sağ, R., Savaş, B., \& Sezer, R. (2009). Characteristics, problems and needs of multigrade class teachers in Burdur. Inonu University Journal of the Faculty of Education (INUJFE), 10(1), 37-56.

Sarı, M. H., \& Altun, Y. (2015). Göreve yeni başlayan sınıf öğretmenlerinin karşılaştıkları sorunlar. Hacettepe Üniversitesi Ĕ̆itim Fakültesi Dergisi, 30(1), 213-226.

Schleicher, A. (2012). Preparing teachers and developing school leaders for the 21st Century: Lessons from around the World. OECD Publishing. http://dx.doi.org/10.1787/9789264174559-en adresinden erişildi.

Selvi, M., Doğru, M., Gencosman, T., \& Saka, D. (2017). Fen bilimleri öğretmen adaylarının okul deneyimi ve öğretmenlik uygulaması derslerine ilişkin görüşlerinin etkinlik kuramına göre incelenmesi. Ondokuz Mayıs Üniversitesi Ĕ̆itim Fakültesi Dergisi, 36(1), 175-194.

Semerci, Ç. (2011). Mikro öğretim uygulamalarının çok-yüzeyli Rasch ölçme modeli ile analizi. Eğitim ve Bilim, 36(161), 14-25.

Sudweeks, R. R., Reeve, S., \& Bradshaw, W. S. (2005). A comparison of generalizability theory and manyfacet Rasch measurement in an analysis of college sophomore writing. Assessing Writing, 9, 239-261.

Sünbül, A. M. (2005). Bir meslek olarak öğretmenlik. Ö. Demirel ve Z. Kaya (Ed), Öğretmenlik mesleğine giriş (s. 245-278) içinde. Ankara. Pegem A Yayıncılık.

Şahin, A., \& Analı, K. C. (2019). Türkiye'nin doğu illerinde görev yapan aday sınıf öğretmenlerinin karşılaştıkları sorunlar. Okuma Yazma Eğitimi Araştırmaları, 7(1), 37-50.

Şimşek, S., Alkan, V., \& Erdem, A. R. (2013). Öğretmenlik uygulamasına ilişkin nitel bir çalışma. Pamukkale Üniversitesi Ĕ̆itim Fakültesi Dergisi, 34, 63-73.

Taşdere, A. (2014). Sınıf öğretmen adaylarının öğretmenlik uygulaması dersine yönelik yaşadıkları sorunlar ve çözüm önerileri. Turkish Studies International Periodical for the Languages, Literature and History of Turkish or Turkic, 9(2), 1477-1497. 


\section{Süleyman DEMIR}

Wright, B. D., \& Linacre, M. (1994). Reasonable mean-square fit values. Rasch Measurement Transactions, 8(3), 370.

Yuen Fun, I, W. (1991). Toward an Agenda for Helping the Beginning Teacher: Perceptions of Concerns and Best Help Strategies, Annual Conference of the Eastern Educational Research Association, Boston, MA.

Yüzüak, A. V., Yüzüak, B., \& Kaptan, F. (2015). Performans görevinin akran gruplar ve öğretmen yaklaşımları doğrultusunda çok-yüzeyli Rasch ölçme modeli ile analizi. Ĕ̆itimde ve Psikolojide Ölçme ve Değerlendirme Dergisi, 6(1), 1-11.

Zhu, W., Ennis, C.D., \& Chen, A. (1998). Many-faceted Rasch modelling expert judgment in test development. Measurement in Physical Education and Exercise Science, 1(2), 21-39. 
Öğretmen Adaylarının Örnek Olaylara Ait Çözüm...

\section{EXTENDED ABSTRACT}

\section{Introduction}

Preservice teachers see themselves as inadequate in classroom management, implementation of teaching methods and techniques, field knowledge, communication, assessment, and evaluation (Bay, Şeker and Alisinanoğlu, 2020; Karadüz, Eser, Şahin and İlbay, 2009; Selvi, Doğru, Gencosman and Saka, 2017; Taşdere, 2014). They also believe that teaching practice time is insufficient, and they want more practice hours (Altıntaş and Görgen, 2014; Aslan and Sağlam, 2018; Eraslan, 2009; Kavas and Bugay, 2009; Selvi et al., 2017; Taşdere, 2014). Additionally, teacher candidates state that their applications are inadequate and ineffective because they are too short, they are conducted with too many people on the same day, and mentor teachers either do not trust the teacher candidates or they trust the candidates too much (Boz and Boz 2006; Taşdere, 2014). It is likely that the curriculum practices related to implementation are inadequate and ineffective, causing the teacher candidates to fail and lose their self-confidence right when they are ready to begin teaching. It is inevitable that teacher candidates who do not have enough practice opportunities will find classroom settings challenging and fail to cope with the problems they encounter when they start professional life. Classroom teachers' problem-solving strategies can have considerable impacts on students' entire lives considering that they are among the first teachers that students encounter.

\section{Method}

Twenty-one classroom teachers working in public schools under the Republic of Turkey Ministry of National Education were consulted about the problems they had with students in their professional lives that they had difficulty resolving. The problems the teachers reported encountering most frequently were students wetting themselves, theft, foreign students' difficulties adapting, and students being excluded from the mainstream. Since the national education directorates offer in-service trainings on helping foreign students adapt and on mainstreaming students, the two case studies in this paper highlighted wetting and theft as problems new teachers are likely to encounter.

The two case studies were presented to a group of 38 students who graduated from Sakarya University, Faculty of Education, Classroom Teaching Program. The students' proposed strategies were evaluated by four scorers-two specialists in classroom teaching and two experts in guidance and psychological counseling-using the Solution Strategies Evaluation Rubric and the Rasch model with four facets: event, rater, item, and individual.

\section{Results}

The analysis results revealed no differences between the raters' evaluations of the 38 preservice teachers' solution strategies to the case study problems; their evaluations aligned closely in terms of rigidity and generosity. In their solution strategies, the teachers most easily met the criterion of acting calmly during crisis situations and had the most difficulty explaining their proposed interventions to students. Further, according to the four-facet Rasch model in which two sample cases were examined together, teacher number 21 's solution strategy was rated the most successful, and the most unsuccessful one was that of teacher number 26.

\section{Conclusion}

A calibration map revealed a logit value of $19 \%$ for prospective teachers, which was below 0 . Considering that a logit value of 0 expresses the average in the calibration map (Linacre, 1994), in this study, $19 \%$ of the teacher candidates' solution strategies could be considered unsuccessful. The inability of classroom teacher candidates near graduation to produce effective solutions for common problems in the classroom will have negative effects on future students. Among the reasons these teacher candidates failed to resolve issues in these case studies are insufficient hours of practice, lack of opportunity to teach students at all levels, and not being seen as a teacher at school (Aslan and Sağlam, 2018; Aytaçl1, 2012; Eraslan, 2009; Görgen, Çokçıskan and Korkut, 2012; Hudson, Uşak and Savran Gencer, 2010; Kavas and Bugay, 2009; Selvi et al., 2017; Şimşek, Alkan and Erdem, 2013; Taşdere, 2014). Studies have shown that to increase the 
professional readiness of preservice teachers, teacher candidates need a greater number of and longer applications earlier in their education, and they need more interactions with mentor teachers. 


\section{EK.1}

\section{Birinci Örnek Olay:}

Ayberk İlkokul 1. Sınıfa yeni başlamış bir öğrencidir. Ayberk her ne kadar eğitim-öğretime yeni başlamışsa da çalışkanlığı, terbiyesi ve başarısıyla diğer arkadaşlarından sıyrılmış öğretmenin gözünde ve kalbinde bir sevgi oluşturmayı başarmıştır. Bir gün derste öğretmeni Ayberk'in sıkıntılı olduğunu fark etmiş teneffüste konuşurum diyerek dersine devam etmiştir. Ancak Ayberk teneffüse kadar dayanamamış ve altına kaçırmıştır. Ayberk'in bu durumunu öğretmeninden başka kimse fark etmemiştir.

Siz Ayberk'in öğretmeni olsaydınız, Ayberk'in bu davranışını ortadan kaldırmak ve diğer öğrencilerle de böyle bir durumla karşılaşmamak için olay olduğu anda ve daha sonrasında nasıl müdahale ederdiniz?

\section{İkinci Örnek Olay:}

Necati, ilkokul 3. Sınıf öğrencisidir. Babasının işi gereği okulunu değiştirmek zorunda kalmıştır. Yeni başladığı okulda arkadaşlarıyla etkili bir iletişim kuramamaktadır. Teneffüslerde genelde tek başına hareket etmektedir. Sınıf öğretmeni olan Meral Hanım bu durumu fark etmiştir. Sınıftaki bazı öğrencileri yanına çağırarak Necati ile arkadaşlık yapmalarını ve O'nu da oyunlarda aralarına almalarını istemiştir. Birkaç hafta sonra Meral öğretmen sınıfa girmiş ve en ön sırada oturan Mesut'un ağladığını görmüştür. Nedenini sorduğunda ise, "annesinin yeni aldığı suluğunun kaybolduğunu" öğrenmiştir. Meral öğretmen sinif içerisinde biraz incelemeler yaptıktan sonra suluğun Necati'nin çantasında olduğunu görmüştür.

Yukarıda sözü edilen Meral öğretmenin yaşadığı bu durumu bir sınıf öğretmeni olarak sizin yaşadığınızı farz edin. Bu sorunu en güzel bir şekilde sonlandırmak için, sorunun yaşandığı anda ve sonrasında neler yapacağınızı ayrıntılı bir şekilde anlatınız. 


\begin{tabular}{|c|c|c|c|c|c|}
\hline & 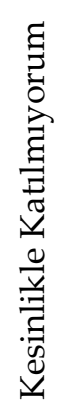 & 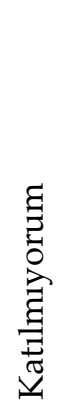 & 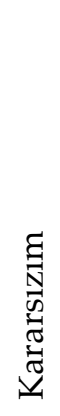 & 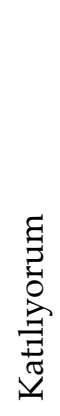 & 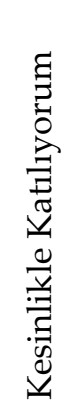 \\
\hline \multicolumn{6}{|l|}{ Öğretmen adayı kriz anında soğukkanlı davranabilmiştir. } \\
\hline \multicolumn{6}{|l|}{$\begin{array}{l}\text { Kriz anından itibaren davranışı ortadan kaldırmaya yönelik öğrenci ile } \\
\text { etkili bir iletişim sağlanmıştır. }\end{array}$} \\
\hline \multicolumn{6}{|l|}{$\begin{array}{l}\text { Yapılan müdahale istenmeyen davranışı kalıcı olarak kaldırmaya } \\
\text { yöneliktir. }\end{array}$} \\
\hline \multicolumn{6}{|l|}{$\begin{array}{l}\text { Yapılan müdahale ileride ortaya çıkması muhtemel benzer problemleri } \\
\text { önlemeye yöneliktir. }\end{array}$} \\
\hline \multicolumn{6}{|l|}{ Yapılan müdahalenin gerekçesi öğrenciye anlatılmıştır. } \\
\hline \multicolumn{6}{|l|}{ Yapılan müdahale rencide edici değildir. } \\
\hline \multicolumn{6}{|l|}{ Müdahale kriz anında başlayarak devam eden bir süreçtir. } \\
\hline $\begin{array}{l}\text { Kriz ve yapılan müdahaleye yönelik bilgi, ilgili kişilere (aile, okul yönetimi } \\
\text { vb) verilmiştir. }\end{array}$ & & & & & \\
\hline
\end{tabular}

